(c) American Dairy Science Association, 2003.

\title{
Milk Conjugated Linoleic Acid Response to Fish Oil Supplementation of Diets Differing in Fatty Acid Profiles ${ }^{1}$
}

\author{
A. A. AbuGhazaleh², D. J. Schingoethe, A. R. Hippen, \\ and K. F. Kalscheur \\ Dairy Science Department, South Dakota State University, \\ Brookings 57007-0647
}

\begin{abstract}
The objective of this experiment was to examine the effect of feeding fish oil (FO) along with fat sources that varied in their fatty acid compositions (high stearic, high oleic, high linoleic, or high linolenic acids) to determine which combination would lead to maximum conjugated linoleic acid (cis-9,trans-11 CLA) and transvaccenic acid (TVA) concentrations in milk fat. Twelve Holstein cows (eight multiparous and four primiparous cows) at $73( \pm 32)$ DIM were used in a $4 \times 4$ Latin square with 4 -wk periods. Treatment diets were 1) $1 \%$ FO plus $2 \%$ fat source high in stearic acid (HS), 2) $1 \%$ FO plus $2 \%$ fat from high oleic acid sunflower seeds (HO), 3) $1 \%$ FO plus $2 \%$ fat from high linoleic acid sunflower seeds (HLO), and 4) $1 \%$ FO plus $2 \%$ fat from flax seeds (high linolenic; HLN). Diets formulated to contain $18 \%$ crude protein were composed of $50 \%$ (dry basis) concentrate mix, $25 \%$ corn silage, $12.5 \%$ alfalfa haylage, and $12.5 \%$ alfalfa hay. Milk production (35.8, 36.3, 34.9, and 35.0 $\mathrm{kg} / \mathrm{d}$ for diets 1 to 4 ) was similar for all diets. Milk fat percentages $(3.14,2.81,2.66$, and 3.08) and yields (1.13, $1.02,0.93$, and $1.08 \mathrm{~kg} / \mathrm{d}$ ) for diets 1 to 4 were lowest for HLO. Milk protein percentages $(3.04,3.03,3.10$, and $3.08)$ and dry matter intake (DMI) $(25.8,26.0,26.2$, and $26.2 \mathrm{~kg} / \mathrm{d}$ ) for diets 1 to 4 were similar for all diets. Milk cis-9,trans-11 CLA concentrations $(0.70,1.04,1.70$, and $1.06 \mathrm{~g} / 100 \mathrm{~g}$ fatty acids) for diet 1 to 4 and yields (7.7, $10.7,15.8$, and $11.3 \mathrm{~g} / \mathrm{d}$ ) for diets 1 to 4 were greatest with HLO and were least with HS. Milk cis-9,trans-11 CLA concentrations and yields were similar for cows fed the HO and the HLN diets. Similar to milk cis9,trans-11 CLA, milk TVA concentration $(1.64,2.49$, 3.74 , and $2.41 \mathrm{~g} / 100 \mathrm{~g}$ fatty acids) for diets 1 to 4 was
\end{abstract}

\footnotetext{
Received July 21, 2002.

Accepted November 2, 2002.

Corresponding author: D. J. Schingoethe; e-mail: david schingoethe@sdstate.edu.

${ }^{1}$ Published with the approval of director of the South Dakota Agricultural Experiment Station as Publication Number \# 3322 of the Journal Series.

${ }^{2}$ Present address: Department of Animal and Veterinary Science, Clemson University, Clemson, SC 29634.
}

greatest with the HLO diet and least with the HS diet. Feeding a high linoleic acid fat source with fish oil most effectively increased concentrations and yields of milk cis-9,trans-11 CLA and TVA.

(Key words: conjugated linoleic acid, transvaccenic acid, milk fatty acids)

Abbreviation key: CLA = conjugated linoleic acid, $\mathbf{E C M}=$ energy-corrected milk, $\mathbf{E E}$ = ether extract, $\mathbf{F A}$ = fatty acid, $\mathbf{F O}=$ fish oil, HLO = high linoleic acid, $\mathbf{H L N}=$ high linolenic acid, HO = high oleic acid, $\mathbf{H S}=$ high stearic acid, TVA = transvaccenic acid.

\section{INTRODUCTION}

Conjugated linoleic acids (CLA) are positional and geometric isomers of linoleic acid (C18:2 cis-9,cis-12). The cis-9,trans- 11 isomer is the predominantly naturally occurring CLA in foods derived from ruminants. Because potential health benefits have been associated with dietary consumption of cis-9,trans-11 CLA (Belury, 1995; Parodi, 1997), enhancement of cis-9,trans11 CLA concentrations in meat and milk has become an important objective. Linoleic acid and linolenic acid (C18:3 cis-9,cis-12,cis-15; n3), which are the major polyunsaturated fatty acids (FA) in animal diets, are precursors for synthesis of cis-9,trans-11 CLA during the ruminal biohydrogenation process (Harfoot and Hazlewood, 1988). Although some of the cis-9,trans-11 CLA may escape the rumen into the intestine; the vast majority of this is further biohydrogenated and converted into trans-11 C18:1 (transvaccenic acid, TVA; Chilliard et al., 2000). Transvaccenic acid can escape the rumen into the intestine or be further biohydrogenated in the rumen into stearic acid (C18:0; Chilliard et al., 2000). Unlike linoleic acid, biohydrogenation of linolenic acid in the rumen leads to the formation of TVA, not CLA (Harfoot and Hazlewood, 1988). As with ruminant tissues, human tissues have delta-9 desaturase that is capable of synthesizing cis-9,trans-11 CLA from TVA (Salminen et al., 1998). For many years, scientists believed that linoleic acid and linolenic acid were the only precursors for CLA production. However, a recent study 
by Mosley et al. (2002) demonstrated that oleic acid (C18:1 cis-9), which previously was thought to be only biohydrogenated into stearic acid, may also be a precursor for several trans fatty acid isomers, including TVA.

Our previous research (Donovan et al., 2000; AbuGhazaleh et al., 2002; Whitlock et al., 2002) demonstrated that dietary inclusion of fish oil (FO) increased milk cis-9,trans-11 CLA and TVA concentrations. Milk cis-9,trans-11 CLA and TVA concentrations were increased 360 and $430 \%$, respectively, when fish oil was fed at $2 \%$ of diet DM (Donovan et al., 2000). When fed $2 \%$ fat from extruded soybeans, a major source of linoleic acid, milk cis-9,trans-11 CLA and TVA concentrations increased by 200 and $230 \%$, respectively (Whitlock et al., 2002). Because FO has a very low concentration $(<7 \%)$ of oleic, linoleic, and linolenic acids, we hypothesized that a component in FO may serve as a ruminal modifier causing greater than expected increases in milk cis-9,trans-11 CLA and TVA concentrations from dietary linoleic and linolenic acids. This hypothesis was supported by the finding of Whitlock et al. (2002) and AbuGhazaleh et al. (2002) who reported that the increase in milk cis-9,trans-11 CLA and TVA concentrations when cows were fed a blend of FO and extruded soybeans was greater than the additive effect of feeding both fat sources separately. Therefore, the objective of this study was to measure milk cis-9,trans-11 CLA and TVA responses to dietary inclusion of FO with other fat sources varying in FA composition.

\section{MATERIALS AND METHODS}

All procedures for this study were carried out under approval by the South Dakota State University Animal Care and Use Committee. Twelve Holstein cows at 73 ( \pm 32) DIM were used in a $4 \times 4$ Latin square with 4 wk periods. Two squares consisted of eight multiparous cows, and the other square consisted of four primiparous cows. Cows within a square were randomly assigned to dietary treatments. Treatment diets (Table 1) were 1) $1 \% \mathrm{FO}$ plus $2 \%$ fat source high in stearic acid (Rumo-fat; HS), 2) $1 \%$ FO plus $2 \%$ fat from high oleic acid sunflower seeds (HO), 3) $1 \%$ FO plus $2 \%$ fat from high linoleic acid (regular oil seed) sunflower seeds (HLO), and 4) 1\% FO plus 2\% fat from flax seeds (high linolenic; HLN). Diets were formulated to contain $18 \%$ $\mathrm{CP}$ and were composed of $50 \%$ (dry basis) concentrate mix, $25 \%$ corn silage, $12.5 \%$ alfalfa haylage, and $12.5 \%$ alfalfa hay. Menhaden fish oil (Omega Protein Inc., Hammond, LA) was used in this experiment. Rumo-fat (Robt Morgan Inc., Paris, IL) was used as a source of stearic acid. Regular sunflower seeds and flax seeds were obtained from local dealers. A local farmer donated the high oleic sunflower seeds. Sunflower and flax seed shells were cracked by rollers; however, because flax seeds are quite small, most of the seed shells remained intact.

Cows were housed in a free-stall barn and fed using Calan Broadbent feeder doors (American Calan, Inc., Northwood, NH) for individual feed intakes. Cows were placed in the free-stall area and assigned to Calan feeding doors $1 \mathrm{wk}$ before feeding the treatment diets to allow for acclimation. Cows were individually fed a TMR once daily (1030 h) for ad libtium consumption with continuous access to feed except during milking. Amounts fed and refused were recorded daily. Before the experiment, cows were fed a 55:45 concentrate to forage diet. Corn silage, alfalfa hay, and alfalfa haylage composed the forage fraction, while ground corn, whole cotton seeds, and soybean meal were the main ingredients in the concentrate mix.

Cows were milked daily at 0600,1400 , and $2100 \mathrm{~h}$, and milk yield was recorded at each milking during the final $7 \mathrm{~d}$ of each period. Milk samples from the three daily milkings were collected on three consecutive days (d 26, 27, and 28) of each period. Three 24-h composites, amounts proportional to milk yield at each time, of each cow's milk were split into two portions for analysis. One portion was refrigerated at $4^{\circ} \mathrm{C}$ and sent to a laboratory (Valley Queen Cheese Factory, Milbank, SD) to be analyzed for fat, protein, lactose and SNF (AOAC, 1997) by midinfrared spectrophotometry (Multispec; Foss Food Technology Corp., Eden Prairie, MN); SCC (AOAC, 1997) were determined using a Fossomatic 90 (Foss Food Technology Corp., Eden Prairie, MN). The other portion of each sample was stored at $-20^{\circ} \mathrm{C}$ for analysis of fatty acids by GLC as described by AbuGhazaleh et al. (2002).

Samples of alfalfa hay, alfalfa haylage, corn silage, and concentrate mixes were collected weekly and stored at $-20^{\circ} \mathrm{C}$ until analyses. Weekly samples were dried at $55^{\circ} \mathrm{C}$ in a Despatch oven (style V-23; Despatch Oven Co., Minneapolis, MN) for at least $24 \mathrm{~h}$, then ground through a 2-mm screen of a standard Wiley mill (model 3; Arthur H. Thomas Co., Philadelphia, PA) and composited by period. Subsamples of feed composites were dried at $105^{\circ} \mathrm{C}$ for $24 \mathrm{~h}$ to correct to $100 \% \mathrm{DM}$. Composites were analyzed for CP, ether extract (EE), and ash according to AOAC (1997) methods. Samples were reground (Brinkman ultracentrifuge mill) through a 1$\mathrm{mm}$ screen prior to analyses for $\mathrm{Ca}, \mathrm{P}, \mathrm{Mg}$ (AOAC, 1997), and fiber. Neutral detergent fiber (procedure $B$ of ), ADF (Robertson and Van Soest, 1981), and acid detergent lignin (Lowry et al., 1994) were determined by ANKOM fiber analyzer using Filter Bag Technique (ANKOM Technology Corp., Fairport, NY). Body weight and BCS (Wildman et al., 1982) were recorded at the beginning of the trial and the end of each period. 
Table 1. Ingredient and nutrient content of experimental diets.

\begin{tabular}{|c|c|c|c|c|}
\hline \multirow[b]{2}{*}{ Item } & \multicolumn{4}{|c|}{$\operatorname{Diet}^{1}$} \\
\hline & HS & $\mathrm{HO}$ & HLO & HLN \\
\hline & & - & & 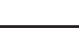 \\
\hline \multicolumn{5}{|l|}{ Ingredient composition } \\
\hline Alfalfa hay & 12.50 & 12.50 & 12.50 & 12.50 \\
\hline Haylage & 12.50 & 12.50 & 12.50 & 12.50 \\
\hline Corn silage & 25.00 & 25.00 & 25.00 & 25.00 \\
\hline Cracked corn & 26.70 & 27.00 & 27.42 & 27.56 \\
\hline Soybean meal & 14.50 & 13.50 & 13.34 & 12.54 \\
\hline Fish oil & 1.00 & 1.00 & 1.00 & 1.00 \\
\hline Rumo-fat ${ }^{2}$ & 2.00 & & $\ldots$ & $\ldots$ \\
\hline Sunflower seeds, high oleic & $\ldots$ & 4.60 & $\ldots$ & $\ldots$ \\
\hline Sunflower seeds, high linoleic & $\ldots$ & $\ldots$ & 4.34 & \\
\hline Flaxseeds & $\ldots$ & . & $\ldots$ & 5.00 \\
\hline Soy hulls & 3.50 & 1.60 & 1.60 & 1.60 \\
\hline High $\mathrm{Zn}$ trace mineralized salt ${ }^{3}$ & 0.20 & 0.20 & 0.20 & 0.20 \\
\hline Magnesium oxide & 0.14 & 0.14 & 0.14 & 0.14 \\
\hline Dicalcium phosphate & 0.60 & 0.60 & 0.60 & 0.60 \\
\hline Limestone & 1.00 & 1.00 & 1.00 & 1.00 \\
\hline Vitamin A, D, and E premix ${ }^{4}$ & 0.10 & 0.10 & 0.10 & 0.10 \\
\hline Vitamin E premix ${ }^{5}$ & 0.06 & 0.06 & 0.06 & 0.06 \\
\hline \multicolumn{5}{|l|}{ Chemical composition } \\
\hline $\mathrm{DM}, \%$ & 58.10 & 58.90 & 58.40 & 58.80 \\
\hline $\mathrm{CP}$ & 16.40 & 16.75 & 16.68 & 16.91 \\
\hline RUP, ${ }^{6} \%$ of $\mathrm{CP}$ & 33.40 & 33.10 & 36.90 & 35.00 \\
\hline Ether extract & 5.75 & 5.42 & 5.70 & 5.48 \\
\hline Total fatty acids & 3.62 & 3.74 & 3.76 & 3.67 \\
\hline $\mathrm{ADF}$ & 19.14 & 18.64 & 18.29 & 19.03 \\
\hline $\mathrm{NDF}$ & 29.87 & 29.33 & 29.19 & 30.04 \\
\hline Lignin & 2.94 & 3.03 & 3.02 & 3.02 \\
\hline Ash & 6.94 & 7.02 & 6.81 & 6.85 \\
\hline $\mathrm{Ca}$ & 1.05 & 1.09 & 1.05 & 0.98 \\
\hline $\mathrm{P}$ & 0.43 & 0.45 & 0.43 & 0.41 \\
\hline $\mathrm{Mg}$ & 0.32 & 0.30 & 0.34 & 0.34 \\
\hline $\mathrm{NE}_{\mathrm{L}}^{6}, \mathrm{Mcal} / \mathrm{kg}$ & 1.80 & 1.76 & 1.76 & 1.74 \\
\hline
\end{tabular}

${ }^{1} \mathrm{HS}=1 \%$ fish oil $+2 \%$ fat source high in stearic acid $\mathrm{HO}=1 \%$ fish oil $+2 \%$ fat from high oleic acid sunflower seeds; $\mathrm{HLO}=1 \%$ fish oil $+2 \%$ fat from high linoleic acid sunflower seeds; and HLN $=1 \%$ fish oil $+2 \%$ fat from flaxseeds (high linolenic).

${ }^{2}$ Rumo-fat (Robt Morgan Inc., Paris, IL).

${ }^{3}$ Contained (\%): $\mathrm{NaCl}$ (95.5-98.8), $\mathrm{Zn}$ (1.00), $\mathrm{Mn}$ (0.75), $\mathrm{Fe}$ (0.60), $\mathrm{Mg}$ (0.05), $\mathrm{Cu}$ (0.032), I (0.028), and Co (0.011).

${ }^{4}$ Contained 4,400,000 IU of vitamin A; 880,000 IU of vitamin D, and $440 \mathrm{IU}$ of vitamin $\mathrm{E}$ per $\mathrm{kg}$.

${ }^{5}$ Contained 44,000 IU of vitamin E per kg.

${ }^{6}$ Estimated from NRC (2001).

Samples of alfalfa hay, alfalfa haylage, corn silage, and concentrate mix were composited into TMR within each treatment period, and fat was extracted in a mixture of ether and acetone (1:1 vol/vol). Approximately $15 \mathrm{mg}$ of the extracted fat was transferred into $13-\times$ 100-mm test tubes with Teflon-lined screw caps and then analyzed for FA as described by AbuGhazaleh et al. (2002). C17:0 FA, dissolved in butanol, was used as an internal standard.

Data were analyzed using PROC MIXED of SAS (1996). Fixed effects were period, treatment, and square, while random effects were cows within square. Least significant difference at $P<0.05$ was used to determine significant differences among means. Model effects were considered significant at $P<0.05$.

\section{RESULTS AND DISCUSSION}

A summary of dietary ingredients and chemical composition of the experimental diets is shown in Table 1. Total mixed diets contained similar DM, CP, ADF, and NDF. Acid detergent fiber and NDF contents for the HS were balanced by adding additional soy hulls (Table 1). Ether extract concentration for HO and HLN diets was lower than anticipated because fat contents of high oleic sunflower seeds and flaxseeds were slightly lower than values used to formulate the diet. Total FA were measured because they represent a more true nutritional value of dietary fat than does ether extract. The four fat supplements used in the study were chosen because of the differences in their FA composition (Ta- 
Table 2. Fatty acid composition of fat supplements and fish oil.

\begin{tabular}{|c|c|c|c|c|c|}
\hline Fatty acids $^{1}$ & Rumo-fat & $\begin{array}{l}\text { Oleic } \\
\text { sunflower } \\
\text { seeds }\end{array}$ & $\begin{array}{l}\text { Regular } \\
\text { sunflower } \\
\text { seeds }\end{array}$ & Flaxseeds & Fish oil \\
\hline$C 14: 0$ & 2.81 & 0.04 & 0.07 & 0.05 & 7.70 \\
\hline$C 16: 0$ & 22.11 & 3.79 & 5.87 & 5.66 & 17.10 \\
\hline$C 16: 1$ & 0.05 & $\mathrm{nd}^{2}$ & nd & nd & 10.26 \\
\hline$C 18: 0$ & 64.20 & 3.42 & 4.18 & 3.76 & 3.21 \\
\hline$C 18: 1 c 9$ & 1.10 & 83.90 & 26.45 & 20.92 & 6.97 \\
\hline$C 18: 2 c 9 c 12$ & 0.88 & 4.29 & 59.95 & 16.60 & 1.31 \\
\hline$C 18: 3 n 3$ & 0.05 & 0.22 & 0.14 & 50.12 & 1.10 \\
\hline$C 20: 5(\mathrm{EPA})^{3}$ & nd & nd & nd & nd & 10.93 \\
\hline$C 22: 6(\mathrm{DHA})^{4}$ & nd & nd & nd & nd & 11.92 \\
\hline
\end{tabular}

${ }^{1}$ Expressed as number of carbons:number of double bonds.

${ }^{2} \mathrm{nd}=$ not detectable or detected at $<0.01 \mathrm{~g} / 100 \mathrm{~g}$ of fatty acids.

${ }^{3} \mathrm{EPA}=$ eicosapentaenoic acid.

${ }^{4} \mathrm{DHA}=$ docosahexaenoic acid.

ble 2). The major FA in the various fat sources were Rumo-fat, stearic acid (64.2\%); high oleic sunflower seeds, oleic acid (83.9\%); regular sunflower seeds, linoleic acid (60\%); and flax seeds, linolenic acid (50.1\%). The regular sunflower seeds contained a lower proportion of linoleic acid than was typical for oilseed varieties (Casper et al., 1988; Stegeman et al., 1992), which indicated that some confectionery variety sunflower seeds may have been mixed in with mostly oilseed varieties. Fish oil was characterized by its content of long chain acids greater than 20 carbons length, being particularly rich in C20:5 n-3 (eicosapentaenoic acid) and C22:6 n3 (docosahexaenoic acid; 10.9 and $11.9 \mathrm{~g} / 100 \mathrm{~g}$ of FA, respectively).

\section{Milk Yield, Milk Composition, and Dry Matter Intake}

Milk production and composition data are presented in Table 3. Milk production did not differ among treatments $(P>0.05)$, averaging $35.5 \pm 0.8 \mathrm{~kg} / \mathrm{d}$. As expected, multiparous cows produced more milk $(P<0.05)$ than primiparous cows averaging 40.5 and $30.4 \mathrm{~kg} / \mathrm{d}$, respectively (data not shown). Milk fat percentages were relatively low for all treatments, averaging $2.92 \%$ compared with a pretreatment average of $3.46 \%$. Milk fat depression commonly is observed when FO and/or unsaturated FA is fed to dairy cows (Palmquist and Jenkins, 1980; AbuGhazaleh et al., 2002; Whitlock et al., 2002). The HO and the HLO depressed milk fat concentration compared with values of the other two diets (Table 3). Cows fed the HS had similar milk fat percentages to cows fed the HLN. The HLO caused the greatest depression in milk fat percentages. Unlike saturated FA, unsaturated FA are known to be toxic to rumen microorganisms (Harfoot, 1981). Banks et al. (1990) suggested that the amount of trans-C18:1 FA that reaches the mammary gland significantly influences the amount and type of FA that are synthesized in this tissue. A recent work by Chouinard et al. (1999) established the pattern of trans FA isomers rather than total trans FA is a key dimension in the development of milk fat depression. They observed that the decrease in milk fat yield was associated with a specific increase in trans-10 C18:1 FA rather than an increase in the total transC18:1 content of milk fat. The concentrations of trans$10 \mathrm{C} 18: 1$ in milk fat was higher $(P<0.05)$ for cows fed the HO and HLO diets (Table 5). However, the mechanism by which the trans isomers of C18:1 FA decrease milk fat content is not known. Both the availability of dietary lipid to ruminal biohydrogenation and the FA composition of dietary lipids affect trans-C18:1 FA production. The lack of milk fat depression with the HLN diet in this experiment compared with the HO and the HLO diets may be related to the decreased accessibility of flaxseed lipids to ruminal microorganisms for hydrolysis and biohydrogenation. Petit (2002) reported lower EE digestibility for whole flaxseeds compared with micronized soybeans and megalac when fed to lactating dairy cows. Petit (2002) speculated that lower accessibility of flaxseed lipids to rumen microbes and enzymes was responsible for that. In addition, we (AbuGhazaleh et al., 2003) observed higher ruminal concentration of C18:3 n3 FA for cows fed the HLN diet, which also support our speculations of lower accessibility of flax seed lipids to ruminal biohydrogenation. The fact that the HO and the HLO diets had similar milk fat percentages $(P>0.19)$ was unexpected since the HO diet was high in monounsaturated FA. The finding of Mosley et al. (2002) that oleic acid is also a precursor for trans-C18:1 FA may explain the depression in milk fat percentages with the $\mathrm{HO}$ diet. Due to depression in milk fat content, the HLO had the lowest fat yields, 
Table 3. Milk yield, milk composition, BW, BCS, and DMI from cows fed fish oil with different fat sources.

\begin{tabular}{|c|c|c|c|c|c|}
\hline \multirow[b]{2}{*}{ Item } & \multicolumn{4}{|c|}{$\operatorname{Diet}^{1}$} & \multirow[b]{2}{*}{$\mathrm{SE}$} \\
\hline & HS & $\mathrm{HO}$ & HLO & HLN & \\
\hline Milk, kg/d & 35.8 & 36.3 & 34.9 & 35.0 & 1.00 \\
\hline $3.5 \%$ FCM, $\mathrm{kg} / \mathrm{d}$ & $33.8^{\mathrm{a}}$ & $32.2^{\mathrm{ab}}$ & $30.1^{\mathrm{b}}$ & $32.7^{\mathrm{a}}$ & 1.12 \\
\hline $\mathrm{ECM}^{2}, \mathrm{~kg} / \mathrm{d}$ & $34.1^{\mathrm{a}}$ & $32.9^{\mathrm{ab}}$ & $31.1^{b}$ & $33.2^{\mathrm{a}}$ & 1.03 \\
\hline \multicolumn{6}{|l|}{ Fat } \\
\hline$\%$ & $3.14^{\mathrm{a}}$ & $2.81^{\mathrm{b}}$ & $2.66^{\mathrm{b}}$ & $3.08^{\mathrm{a}}$ & 0.12 \\
\hline $\mathrm{kg} / \mathrm{d}$ & $1.13^{\mathrm{a}}$ & $1.02^{\mathrm{bc}}$ & $0.93^{\mathrm{c}}$ & $1.08^{\mathrm{ab}}$ & 0.05 \\
\hline \multicolumn{6}{|l|}{ Protein } \\
\hline$\%$ & 3.04 & 3.03 & 3.10 & 3.08 & 0.04 \\
\hline $\mathrm{kg} / \mathrm{d}$ & 1.08 & 1.09 & 1.07 & 1.07 & 0.03 \\
\hline \multicolumn{6}{|l|}{ Lactose } \\
\hline$\%$ & $4.92^{\mathrm{a}}$ & $4.90^{\mathrm{ab}}$ & $4.83^{b}$ & $4.89^{\mathrm{ab}}$ & 0.04 \\
\hline $\mathrm{kg} / \mathrm{d}$ & 1.77 & 1.78 & 1.68 & 1.71 & 0.05 \\
\hline \multicolumn{6}{|l|}{ Total solids } \\
\hline$\%$ & 12.01 & 10.67 & 11.51 & 11.95 & 0.71 \\
\hline $\mathrm{kg} / \mathrm{d}$ & 4.32 & 4.04 & 4.02 & 4.19 & 0.19 \\
\hline $\mathrm{SCC}, \times 10^{3} / \mathrm{ml}$ & $237^{\mathrm{b}}$ & $356^{\mathrm{b}}$ & $669^{\mathrm{a}}$ & $266^{\mathrm{b}}$ & 125.20 \\
\hline $\mathrm{BW}, \mathrm{kg}$ & 613 & 605 & 609 & 611 & 6.00 \\
\hline $\mathrm{BCS}^{3}$ & 3.30 & 3.30 & 3.40 & 3.40 & 0.04 \\
\hline DMI, kg/d & 25.8 & 26.0 & 26.2 & 26.2 & 0.57 \\
\hline
\end{tabular}

3.5\% FCM, and energy-corrected milk (ECM), while the HS and the HLN had the highest fat yield, $3.5 \%$ FCM, and ECM (Table 3).

Milk true protein percentages and yields were similar for all diets (Table 3). Milk protein percentages for all treatments averaged $3.06 \%$ compared with a pretreatment average of $2.98 \%$. Total milk solids percentages and yields as well as BW and BCS were not different among treatments $(P>0.05)$. Somatic cell counts were higher $(P<0.05)$ with the HLO compared with other diets, reflecting a couple of high SCC samples that happened to occur when cows were fed that diet. However, SCC were within acceptable limits, and the high SCC samples were not correlated with decreased milk production.

Dry matter intake did not differ among the four diets $(P>0.05)$. Daily DMI were quite high for all diets, averaging $4.3 \%$ of $\mathrm{BW}$, which could be expected because the cows were in the stage of lactation when the DMI would be highest (NRC, 2001). As with milk production, multiparous cows had higher $(P<0.05)$ DMI than primiparous cows averaging 30.3 and $22.1 \mathrm{~kg} / \mathrm{d}$, respectively (data not shown).

\section{Fatty Acid Composition of Feed and Milk}

Total FA intake averaged 933, 967, 981, and $961 \mathrm{~g} /$ $\mathrm{d}$ for the HS, HO, HLO, and the HLN, respectively.
Differences in FA intake reflect differences in FA composition of the fat supplements (Table 4). For example, the Rumo-fat supplement greatly increased intake of C18:0 FA. The intakes of C18:1 cis-9 and C18:2 cis9,cis-12 FA were also increased when high oleic and regular sunflower seeds were added to diets, respectively. Compared with other diets, addition of flaxseeds greatly increased intake of C18:3 n3 FA. The total daily intake of C18:1 cis-9, C18:2 cis-9,cis-12, and C18:3 n3 FA represented 34.6, 63.5, 66.7, and $67.3 \%$ of total FA intakes for the HS, HO, HLO, and the HLN, respectively. For the HO, intake of C18:1 cis-9, C18:2 cis-9, cis12, and C18:3 n3 (g/d) FA represented 36.7, 21.9, and $4.9 \%$ of total FA, respectively. Daily intake of these three FA for the HLO represented 19.9, 42.4, and 4.4\% of total FA, respectively. For the HLN, the daily intake of C18:1 cis-9, C18:2 cis-9,cis-12, and C18:3 n3 (g/d) FA represented 18.2, 25.9, and $23.2 \%$ of total FA, respectively. Feeding FO is responsible for the higher intake of the omega-3 FA, especially, eicosapentaenoic acid and docosahexaenoic acid in all diets.

The main objective of this study was to determine the effects of dietary oleic, linoleic, and linolenic acids on cis-9,trans-11 CLA and TVA concentration in milk fat. All treatment diets resulted in milk fat concentrations of cis-9,trans-11 CLA that were 75 to $325 \%$ greater than the pretreatment average of $0.40 \mathrm{~g} / 100 \mathrm{~g}$ FA. The concentration and yield of cis-9,trans-11 CLA were in- 
Table 4. Intake of individual fatty acids.

\begin{tabular}{|c|c|c|c|c|c|}
\hline \multirow[b]{2}{*}{ Fatty acids ${ }^{2}$} & \multicolumn{4}{|c|}{ Diet $^{1}$} & \multirow[b]{2}{*}{$\mathrm{SE}$} \\
\hline & HS & $\mathrm{HO}$ & HLO & HLN & \\
\hline & & & & & \\
\hline$C 14: 0$ & 23.33 & 16.71 & 15.56 & 15.17 & 1.09 \\
\hline$C 15: 0$ & 2.84 & 2.03 & 1.84 & 1.85 & 0.13 \\
\hline$C 16: 0$ & 152.92 & 108.54 & 110.38 & 106.70 & 7.40 \\
\hline$C 16: 1$ & 18.94 & 20.74 & 19.52 & 19.22 & 1.18 \\
\hline$C 17: 0$ & 7.32 & 3.05 & 2.54 & 2.25 & 0.26 \\
\hline C18:0 & 213.88 & 40.49 & 38.23 & 34.34 & 6.69 \\
\hline$C 18: 1 c 9$ & 99.99 & 354.85 & 195.70 & 174.51 & 12.17 \\
\hline$C 18: 1 c 11$ & 0.29 & 0.39 & 0.38 & 0.29 & 0.02 \\
\hline$C 18: 2 c 9 c 12$ & 181.59 & 211.82 & 416.01 & 248.77 & 16.80 \\
\hline C20:1 & 0.65 & 0.56 & 0.57 & 0.52 & 0.04 \\
\hline$C 20: 0$ & 8.28 & 4.19 & 4.02 & 3.25 & 0.32 \\
\hline$C 18: 3 n 3$ & 41.43 & 47.26 & 43.03 & 223.39 & 7.48 \\
\hline$C 18: 3 n 6$ & 3.08 & 3.71 & 3.28 & 2.98 & 0.19 \\
\hline$C 21: 0$ & 5.97 & 6.07 & 0.57 & 5.91 & 0.36 \\
\hline$C 20: 2$ & 0.69 & 0.73 & 0.40 & 0.72 & 0.04 \\
\hline$C 20: 3$ & 0.52 & 0.54 & 0.54 & 0.55 & 0.03 \\
\hline$C 22: 0$ & 3.80 & 5.62 & 5.61 & 3.31 & 0.27 \\
\hline$C 22: 1$ & 1.17 & 1.23 & 1.12 & 1.13 & 0.07 \\
\hline$C 20: 5(\mathrm{EPA})^{3}$ & 17.72 & 18.46 & 18.74 & 18.26 & 1.11 \\
\hline$C 22: 6$ (DHA) $^{4}$ & 18.66 & 19.43 & 19.72 & 19.22 & 1.17 \\
\hline Others $^{5}$ & 130.04 & 101.04 & 78.95 & 78.89 & 6.14 \\
\hline
\end{tabular}

${ }^{1} \mathrm{HS}=1 \%$ fish oil $+2 \%$ fat source high in stearic acid; $\mathrm{HO}=1 \%$ fish oil $+2 \%$ fat from high oleic acid sunflower seeds; $\mathrm{HLO}=1 \%$ fish oil $+2 \%$ fat from high linoleic acid sunflower seeds; and HLN $=1 \%$ fish oil $+2 \%$ fat from flaxseeds (high linolenic).

${ }^{2}$ Expressed as number of carbons:double bonds.

${ }^{3} \mathrm{EPA}=$ eicosapentaenoic acid.

${ }^{4} \mathrm{DHA}=$ docosahexaenoic acid.

${ }^{5}$ Unidentified peaks.

creased $(P<0.05)$ when cows were fed the HO, HLO, and the HLN compared with the HS, and were greatest with the HLO (Table 5 and 6). Milk fat concentrations of cis-9,trans-11 CLA did not differ $(P>0.05)$ between cows fed the HO and the HLN. The $75 \%$ increase in milk cis-9,trans-11 CLA with the HS compared with the pretreatment average further supports our previous finding (AbuGhazaleh et al., 2002; Whitlock et al., 2002) that feeding FO can increase production of cis-9,trans11 CLA by stimulating the conversion of linoleic and linolenic acids supplied from other dietary sources. Feeding a blend of FO from fish meal and extruded soybeans (high linoleic acid) increased milk cis-9,trans11 CLA concentration by $321 \%$ of the control (AbuGhazaleh et al., 2002). We are not aware of previous investigations of milk fat CLA with diets containing FO and high oleic or linolenic FA sources. However, others (Kelly et al., 1998; Dhiman et al., 2000; Chouinard et al., 2001) have added plant oil alone or Ca salts of plant oil high in oleic and linolenic acids and observed an increase in milk cis-9,trans-11 CLA concentrations. When Kelly et al. (1998) added peanut oil (high oleic acid), sunflower oil (high linoleic acid), and linseed oil (high linolenic acid) at $5.3 \%$ to the diet of lactating cows, milk CLA concentrations were greatest with the sunflower oil diet, averaging $2.44 \mathrm{~g} / 100 \mathrm{~g}$ fat. The linseed oil diet had numerically higher CLA concentrations (1.67 g/100 fat) compared with peanut oil diet (1.33 g/100 g of fat; Kelly et al., 1998). However, when Chouinard et al. (2001) fed dietary supplements of Ca salts of FA from canola oil (high oleic acid), soybean oil (high linoleic acid), and linseed oil, milk CLA concentrations increased by three- to fivefold over the control diet, being greatest when $\mathrm{Ca}$ salts of soybean oil and linseed oil were fed. The fact that our HLN did not increase cis-9,trans-11 CLA concentrations over the HO might have been due to the low availability of flaxseed oil for ruminal biohydrogenation. Overall, the total daily production of cis-9,trans-11 CLA averaged 7.7, $10.7,15.8$, and $11.3 \mathrm{~g} / \mathrm{d}$ for the HS, HO, HLO, and the HLN, respectively (Table 6).

As with milk cis-9,trans-11 CLA, all treatment diets resulted in milk fat concentrations of TVA that were 82 to $316 \%$ greater than the pretreatment average of $0.90 \mathrm{~g} / 100 \mathrm{~g}$ of FA. The concentration and yield of TVA increased $(P<0.05)$ when cows were fed the HO, HLO, and the HLN compared with the HS, and were greatest with the HLO (Table 5 and 6). However, milk fat concentrations and yields of TVA did not differ $(P>0.05)$ between cows fed the HO and the HLN. Feeding FO 
Table 5. Fatty acid composition of milk fat.

\begin{tabular}{|c|c|c|c|c|c|}
\hline \multirow[b]{2}{*}{ Fatty acids ${ }^{2}$} & \multicolumn{4}{|c|}{$\operatorname{Diet}^{1}$} & \multirow[b]{2}{*}{$\mathrm{SE}$} \\
\hline & HS & $\mathrm{HO}$ & HLO & HLN & \\
\hline & \multicolumn{4}{|c|}{ (g/100 g of fatty acids) } & \\
\hline$C 4: 0$ & $3.65^{\mathrm{a}}$ & $3.34^{\mathrm{b}}$ & $3.06^{\mathrm{c}}$ & $3.51^{\mathrm{ab}}$ & 0.09 \\
\hline C6:0 & $2.15^{\mathrm{a}}$ & $1.84^{\mathrm{c}}$ & $1.65^{\mathrm{d}}$ & $2.02^{\mathrm{b}}$ & 0.06 \\
\hline$C 8: 0$ & $1.28^{\mathrm{a}}$ & $1.06^{\mathrm{c}}$ & $0.94^{\mathrm{d}}$ & $1.19^{\mathrm{b}}$ & 0.04 \\
\hline$C 10: 0$ & $2.86^{\mathrm{a}}$ & $2.36^{\mathrm{c}}$ & $2.09^{\mathrm{d}}$ & $2.61^{\mathrm{b}}$ & 0.10 \\
\hline$C 11: 0$ & $0.05^{\mathrm{a}}$ & $0.04^{\mathrm{b}}$ & $0.03^{\mathrm{b}}$ & $0.04^{\mathrm{b}}$ & $<0.01$ \\
\hline$C 12: 0$ & $3.34^{\mathrm{a}}$ & $2.82^{\mathrm{c}}$ & $2.56^{\mathrm{d}}$ & $3.04^{\mathrm{b}}$ & 0.10 \\
\hline$C 13: 0$ & $0.09^{\mathrm{a}}$ & $0.08^{\mathrm{b}}$ & $0.07^{\mathrm{b}}$ & $0.08^{\mathrm{b}}$ & $<0.01$ \\
\hline$C 14: 0$ & $11.48^{\mathrm{a}}$ & $10.58^{\mathrm{b}}$ & $9.84^{\mathrm{c}}$ & $10.58^{\mathrm{b}}$ & 0.18 \\
\hline$C 14: 1$ & 1.25 & 1.25 & 1.35 & 1.23 & 0.09 \\
\hline$C 15: 0$ & $1.03^{\mathrm{a}}$ & $0.95^{\mathrm{b}}$ & $0.90^{\mathrm{c}}$ & $0.94^{\mathrm{bc}}$ & 0.02 \\
\hline$C 16: 0$ & $27.66^{\mathrm{a}}$ & $23.99^{\mathrm{b}}$ & $23.80^{\mathrm{b}}$ & $24.0^{\mathrm{b}}$ & 0.52 \\
\hline$C 16: 1$ & 1.53 & 1.52 & 1.78 & 1.53 & 0.13 \\
\hline$C 17: 0$ & $0.66^{\mathrm{a}}$ & $0.52^{\mathrm{b}}$ & $0.48^{\mathrm{c}}$ & $0.51^{\mathrm{b}}$ & 0.01 \\
\hline$C 18: 0$ & 8.65 & 9.25 & 8.45 & 8.68 & 0.42 \\
\hline$C 18: 1 t 6-8$ & $0.34^{\mathrm{c}}$ & $0.79^{\mathrm{a}}$ & $0.72^{\mathrm{a}}$ & $0.46^{\mathrm{b}}$ & 0.04 \\
\hline$C 18: 1 t 9$ & $0.37^{\mathrm{c}}$ & $0.69^{\mathrm{a}}$ & $0.69^{\mathrm{a}}$ & $0.47^{\mathrm{b}}$ & 0.03 \\
\hline$C 18: 1 t 10$ & $0.57^{\mathrm{c}}$ & $1.22^{\mathrm{b}}$ & $1.87^{\mathrm{a}}$ & $0.76^{\mathrm{bc}}$ & 0.30 \\
\hline$C 18: 1 t 11$ (TVA) & $1.64^{\mathrm{c}}$ & $2.49^{\mathrm{b}}$ & $3.74^{\mathrm{a}}$ & $2.41^{\mathrm{b}}$ & 0.26 \\
\hline$C 18: 1 c 6$ & $0.57^{\mathrm{c}}$ & $1.22^{\mathrm{b}}$ & $1.87^{\mathrm{a}}$ & $0.76^{\mathrm{bc}}$ & 0.30 \\
\hline$C 18: 1 c 9$ & $17.40^{\mathrm{d}}$ & $20.93^{\mathrm{a}}$ & $19.60^{\mathrm{b}}$ & $18.86^{\mathrm{c}}$ & 0.34 \\
\hline$C 18: 1 c 11$ & $0.50^{\mathrm{c}}$ & $0.51^{\mathrm{c}}$ & $0.86^{\mathrm{a}}$ & $0.62^{\mathrm{b}}$ & 0.04 \\
\hline$C 18: 2 t 9 t 12$ & $0.05^{\mathrm{c}}$ & $0.06^{\mathrm{b}}$ & $0.06^{\mathrm{b}}$ & $0.10^{\mathrm{a}}$ & 0.01 \\
\hline$C 18: 2 c 9 c 12$ & $2.18^{\mathrm{b}}$ & $2.06^{\mathrm{c}}$ & $2.81^{\mathrm{a}}$ & $2.25^{\mathrm{b}}$ & 0.05 \\
\hline$C 20: 0$ & $0.28^{\mathrm{a}}$ & $0.21^{\mathrm{bc}}$ & $0.20^{\mathrm{c}}$ & $0.22^{\mathrm{b}}$ & 0.01 \\
\hline$C 18: 3 n 3$ & $0.75^{\mathrm{b}}$ & $0.71^{\mathrm{b}}$ & $0.65^{\mathrm{c}}$ & $1.19^{\mathrm{a}}$ & 0.02 \\
\hline$C 18: 2 c 9 t 11$ (CLA) & $0.70^{\mathrm{c}}$ & $1.04^{\mathrm{b}}$ & $1.70^{\mathrm{a}}$ & $1.06^{\mathrm{b}}$ & 0.12 \\
\hline$C 18: 2 t 10 c 12$ & $0.02^{\mathrm{c}}$ & $0.07^{\mathrm{b}}$ & $0.12^{\mathrm{a}}$ & $0.03^{\mathrm{c}}$ & 0.01 \\
\hline$C 18: 2 t 9 t 11$ & $0.09^{b}$ & $0.10^{\mathrm{ab}}$ & $0.12^{\mathrm{a}}$ & $0.12^{\mathrm{a}}$ & 0.01 \\
\hline C21:0 & $0.07^{\mathrm{ab}}$ & $0.07^{\mathrm{b}}$ & $0.06^{\mathrm{b}}$ & $0.08^{\mathrm{a}}$ & 0.01 \\
\hline$C 20: 2$ & 0.08 & 0.07 & 0.07 & 0.07 & 0.01 \\
\hline$C 20: 3$ & 0.07 & 0.08 & 0.06 & 0.06 & 0.02 \\
\hline$C 22: 0$ & $0.12^{\mathrm{b}}$ & $0.13^{\mathrm{a}}$ & $0.12^{\mathrm{ab}}$ & $0.10^{\mathrm{c}}$ & $<0.01$ \\
\hline$C 22: 1$ & 0.10 & 0.08 & 0.09 & 0.09 & 0.01 \\
\hline$C 20: 4$ & $0.23^{\mathrm{a}}$ & $0.21^{\mathrm{b}}$ & $0.21^{\mathrm{b}}$ & $0.21^{\mathrm{b}}$ & 0.01 \\
\hline C23:0 & $0.11^{\mathrm{b}}$ & $0.11^{\mathrm{b}}$ & $0.11^{\mathrm{b}}$ & $0.12^{\mathrm{a}}$ & $<0.01$ \\
\hline$C 20: 5(\mathrm{EPA})^{3}$ & $0.14^{\mathrm{a}}$ & $0.10^{\mathrm{c}}$ & $0.10^{\mathrm{c}}$ & $0.12^{\mathrm{b}}$ & $<0.01$ \\
\hline$C 22: 5$ & 0.13 & 0.13 & 0.12 & 0.12 & 0.01 \\
\hline$C 22: 6(\mathrm{DHA})^{4}$ & $0.16^{\mathrm{a}}$ & $0.13^{\mathrm{b}}$ & $0.13^{\mathrm{b}}$ & $0.15^{\mathrm{a}}$ & 0.01 \\
\hline Others $^{5}$ & $8.01^{\mathrm{c}}$ & $8.14^{\mathrm{cb}}$ & $8.54^{\mathrm{b}}$ & $10.08^{\mathrm{a}}$ & 0.23 \\
\hline Short ${ }^{6}$ & $13.42^{\mathrm{a}}$ & $11.53^{\mathrm{c}}$ & $10.40^{\mathrm{d}}$ & $12.50^{\mathrm{b}}$ & 0.34 \\
\hline Medium $^{7}$ & $43.59^{\mathrm{a}}$ & $38.82^{\mathrm{b}}$ & $38.17^{\mathrm{b}}$ & $38.79^{b}$ & 0.70 \\
\hline Long $^{8}$ & $34.98^{\mathrm{c}}$ & $41.52^{\mathrm{a}}$ & $42.89^{\mathrm{a}}$ & $38.63^{\mathrm{b}}$ & 0.75 \\
\hline Saturated & $63.48^{\mathrm{a}}$ & $57.33^{\mathrm{b}}$ & $54.38^{\mathrm{c}}$ & $57.74^{\mathrm{b}}$ & 0.91 \\
\hline Unsaturated & $28.51^{\mathrm{d}}$ & $34.53^{\mathrm{b}}$ & $37.08^{\mathrm{a}}$ & $32.18^{c}$ & 0.81 \\
\hline
\end{tabular}

a,b,c,d Means in the same rows with unlike superscripts differ $(P<0.05)$.

${ }^{1} \mathrm{HS}=1 \%$ fish oil $+2 \%$ fat source high in stearic acid; $\mathrm{HO}=1 \%$ fish oil $+2 \%$ fat from high oleic acid sunflower seeds; $\mathrm{HLO}=1 \%$ fish oil $+2 \%$ fat from high linoleic acid sunflower seeds; and HLN $=1 \%$ fish oil $+2 \%$ fat from flaxseeds (high linolenic).

${ }^{2}$ Expressed as number of carbons:double bonds.

${ }^{3} \mathrm{EPA}=$ eicosapentaenoic acid.

${ }^{4} \mathrm{DHA}=$ docosahexaenoic acid.

${ }^{5}$ Unidentifiable peaks.

${ }^{6}$ Short-chain FA: $(C 4: 0$ to $C 13: 0)$.

${ }^{7}$ Medium-chain FA: $(C 14: 0$ to $C 17: 1)$.

${ }^{8}$ Long-chain FA: $(\geq C 18: 0)$.

(Donovan et al., 2000) or FO as fish meal with extruded soybeans (AbuGhazaleh et al., 2002) increased milk TVA concentrations by three- to fivefold. When Chouinard et al. (2001) fed dietary supplements of Ca salts of
FA from canola oil, soybean oil, and linseed oil, milk TVA concentrations increased and were greatest for cows fed Ca salts of soybean oil, intermediate for cows fed Ca salts of linseed oil, and least for cows fed $\mathrm{Ca}$ 
Table 6. Milk fatty acids yield (g/d).

\begin{tabular}{|c|c|c|c|c|c|}
\hline \multirow[b]{2}{*}{ Fatty acids ${ }^{2}$} & \multicolumn{4}{|c|}{$\operatorname{Diet}^{1}$} & \multirow[b]{2}{*}{$\mathrm{SE}$} \\
\hline & HS & $\mathrm{HO}$ & HLO & HLN & \\
\hline$C 4: 0$ & $41.80^{\mathrm{a}}$ & $34.61^{\mathrm{b}}$ & $29.04^{\mathrm{c}}$ & $39.10^{\mathrm{ab}}$ & 2.41 \\
\hline C6:0 & $24.93^{\mathrm{a}}$ & $19.26^{\mathrm{b}}$ & $15.88^{\mathrm{c}}$ & $22.88^{\mathrm{a}}$ & 2.04 \\
\hline C8:0 & $14.86^{\mathrm{a}}$ & $11.15^{\mathrm{b}}$ & $9.02^{\mathrm{c}}$ & $13.55^{\mathrm{a}}$ & 1.01 \\
\hline$C 10: 0$ & $33.35^{\mathrm{a}}$ & $24.80^{\mathrm{b}}$ & $20.11^{\mathrm{c}}$ & $29.61^{\mathrm{a}}$ & 2.24 \\
\hline$C 11: 0$ & $0.63^{\mathrm{a}}$ & $0.43^{\mathrm{bc}}$ & $0.31^{\mathrm{c}}$ & $0.47^{\mathrm{b}}$ & 0.07 \\
\hline C12:0 & $38.68^{\mathrm{a}}$ & $29.49^{\mathrm{b}}$ & $24.49^{\mathrm{c}}$ & $34.08^{\mathrm{ab}}$ & 2.37 \\
\hline C13:0 & $1.07^{\mathrm{a}}$ & $0.84^{\mathrm{b}}$ & $0.67^{\mathrm{c}}$ & $0.84^{\mathrm{b}}$ & 0.08 \\
\hline$C 14: 0$ & $131.11^{\mathrm{a}}$ & $108.85^{\mathrm{b}}$ & $92.85^{\mathrm{c}}$ & $116.49^{b}$ & 6.64 \\
\hline$C 14: 1$ & $14.38^{\mathrm{a}}$ & $12.94^{\mathrm{ab}}$ & $12.31^{b}$ & $13.44^{\mathrm{ab}}$ & 0.75 \\
\hline$C 15: 0$ & $11.57^{\mathrm{a}}$ & $9.71^{\mathrm{b}}$ & $8.21^{\mathrm{c}}$ & $9.98^{\mathrm{b}}$ & 0.53 \\
\hline$C 16: 0$ & $314.42^{\mathrm{a}}$ & $243.69^{\mathrm{bc}}$ & $220.17^{\mathrm{c}}$ & $259.75^{\mathrm{b}}$ & 15.74 \\
\hline$C 16: 1$ & $16.91^{\mathrm{a}}$ & $15.05^{\mathrm{b}}$ & $15.45^{\mathrm{ab}}$ & $15.79^{\mathrm{ab}}$ & 0.83 \\
\hline$C 17: 0$ & $7.45^{\mathrm{a}}$ & $5.23^{\mathrm{b}}$ & $4.44^{\mathrm{c}}$ & $5.47^{\mathrm{b}}$ & 0.31 \\
\hline C18:0 & $97.45^{\mathrm{a}}$ & $93.70^{\mathrm{ab}}$ & $78.56^{\mathrm{b}}$ & $93.09^{\mathrm{ab}}$ & 7.46 \\
\hline$C 18: 1 t 6-8$ & $3.69^{\mathrm{d}}$ & $8.20^{\mathrm{a}}$ & $6.50^{\mathrm{b}}$ & $4.87^{\mathrm{c}}$ & 0.41 \\
\hline$C 18: 1 t 9$ & $3.97^{\mathrm{d}}$ & $7.09^{\mathrm{a}}$ & $6.32^{\mathrm{b}}$ & $4.98^{\mathrm{c}}$ & 0.33 \\
\hline$C 18: 1 t 10$ & $6.09^{b}$ & $12.27^{\mathrm{a}}$ & $15.85^{\mathrm{a}}$ & $7.83^{\mathrm{b}}$ & 2.02 \\
\hline$C 18: 1 t 11$ (TVA) & $18.10^{\mathrm{c}}$ & $25.71^{\mathrm{b}}$ & $35.51^{\mathrm{a}}$ & $25.99^{\mathrm{b}}$ & 2.78 \\
\hline C18:1c6 & $6.09^{\mathrm{b}}$ & $12.27^{\mathrm{a}}$ & $15.85^{\mathrm{a}}$ & $7.83^{\mathrm{b}}$ & 2.02 \\
\hline$C 18: 1 c 9$ & $192.78^{\mathrm{bc}}$ & $210.78^{\mathrm{a}}$ & $178.98^{\mathrm{c}}$ & $198.85^{\mathrm{ab}}$ & 8.78 \\
\hline$C 18: 1 c 11$ & $5.65^{\mathrm{bc}}$ & $5.20^{\mathrm{c}}$ & $8.24^{\mathrm{a}}$ & $6.78^{\mathrm{b}}$ & 0.58 \\
\hline$C 18: 2 t 9 t 12$ & $0.52^{\mathrm{b}}$ & $0.62^{\mathrm{b}}$ & $0.59^{\mathrm{b}}$ & $1.05^{\mathrm{a}}$ & 0.07 \\
\hline C18:2c9c12 & $24.36^{\mathrm{a}}$ & $20.67^{\mathrm{b}}$ & $26.18^{\mathrm{a}}$ & $24.03^{\mathrm{a}}$ & 1.23 \\
\hline C20:0 & $3.17^{\mathrm{a}}$ & $2.07^{\mathrm{bc}}$ & $1.80^{\mathrm{c}}$ & $2.35^{\mathrm{b}}$ & 0.22 \\
\hline$C 18: 3 n 3$ & $8.29^{b}$ & $7.06^{\mathrm{c}}$ & $5.84^{\mathrm{d}}$ & $13.00^{\mathrm{a}}$ & 0.60 \\
\hline$C 18: 2 c 9 t 11$ (CLA) & $7.68^{\mathrm{c}}$ & $10.65^{\mathrm{b}}$ & $15.79^{\mathrm{a}}$ & $11.30^{\mathrm{b}}$ & 1.02 \\
\hline$C 18: 2 t 10 c 12$ & $0.22^{\mathrm{c}}$ & $0.80^{\mathrm{b}}$ & $1.31^{\mathrm{a}}$ & $0.33^{c}$ & 0.06 \\
\hline$C 18: 2 t 9 t 11$ & $0.99^{\mathrm{b}}$ & $1.03^{\mathrm{ab}}$ & $1.12^{\mathrm{ab}}$ & $1.25^{\mathrm{a}}$ & 0.11 \\
\hline$C 21: 0$ & $0.82^{\mathrm{a}}$ & $0.67^{\mathrm{ab}}$ & $0.51^{\mathrm{b}}$ & $0.82^{\mathrm{a}}$ & 0.13 \\
\hline$C 20: 2$ & $0.88^{\mathrm{a}}$ & $0.71^{\mathrm{b}}$ & $0.68^{\mathrm{b}}$ & $0.77^{\mathrm{ab}}$ & 0.06 \\
\hline C20:3 & 0.80 & 0.90 & 0.52 & 0.66 & 0.23 \\
\hline C22:0 & $1.31^{\mathrm{a}}$ & $1.29^{\mathrm{a}}$ & $1.09^{\mathrm{b}}$ & $1.08^{\mathrm{b}}$ & 0.09 \\
\hline$C 22: 1$ & $1.07^{\mathrm{a}}$ & $0.79^{\mathrm{b}}$ & $0.86^{\mathrm{ab}}$ & $0.98^{\mathrm{ab}}$ & 0.11 \\
\hline$C 20: 4$ & $2.61^{\mathrm{a}}$ & $2.09^{\mathrm{b}}$ & $1.91^{\mathrm{b}}$ & $2.25^{\mathrm{b}}$ & 0.20 \\
\hline C23:0 & $1.24^{\mathrm{ab}}$ & $1.13^{\mathrm{b}}$ & $0.96^{\mathrm{c}}$ & $1.39^{\mathrm{a}}$ & 0.09 \\
\hline$C 20: 5(\mathrm{EPA})^{3}$ & $1.57^{\mathrm{a}}$ & $0.99^{\mathrm{c}}$ & $0.93^{\mathrm{c}}$ & $1.37^{\mathrm{b}}$ & 0.09 \\
\hline C22:5 & $1.51^{\mathrm{a}}$ & $1.37^{\mathrm{ab}}$ & $1.15^{\mathrm{b}}$ & $1.28^{\mathrm{ab}}$ & 0.12 \\
\hline$C 22: 6$ (DHA) ${ }^{4}$ & $1.80^{\mathrm{a}}$ & $1.35^{\mathrm{b}}$ & $1.26^{\mathrm{b}}$ & $1.67^{\mathrm{a}}$ & 0.11 \\
\hline Others $^{5}$ & $90.21^{\mathrm{b}}$ & $84.73^{\mathrm{b}}$ & $83.54^{\mathrm{b}}$ & $107.36^{\mathrm{a}}$ & 8.25 \\
\hline Short $^{6}$ & $155.31^{\mathrm{a}}$ & $120.57^{\mathrm{b}}$ & $99.52^{\mathrm{c}}$ & $140.54^{\mathrm{a}}$ & 9.47 \\
\hline Medium $^{7}$ & $495.85^{\mathrm{a}}$ & $395.46^{\mathrm{bc}}$ & $353.43^{\mathrm{c}}$ & $420.92^{\mathrm{b}}$ & 23.39 \\
\hline Long $^{8}$ & 389.34 & 420.09 & 394.31 & 410.79 & 18.91 \\
\hline Saturated & $723.87^{\mathrm{a}}$ & $586.91^{\mathrm{b}}$ & $508.12^{\mathrm{c}}$ & $630.96^{\mathrm{b}}$ & 38.15 \\
\hline Unsaturated & $316.64^{b}$ & $349.21^{\mathrm{a}}$ & $339.14^{\mathrm{ab}}$ & $341.29^{\mathrm{ab}}$ & 12.33 \\
\hline
\end{tabular}

a,b,c,d Means in the same rows with unlike superscripts differ $(P<0.05)$.

${ }^{1} \mathrm{HS}=1 \%$ fish oil $+2 \%$ fat source high in stearic acid; $\mathrm{HO}=1 \%$ fish oil $+2 \%$ fat from high oleic acid sunflower seeds; HLO $=1 \%$ fish oil $+2 \%$ fat from high linoleic acid sunflower seeds; and HLN = $1 \%$ fish oil $+2 \%$ fat from flaxseeds (high linolenic).

${ }^{2}$ Expressed as number of carbons:double bonds.

${ }^{3} \mathrm{EPA}=$ eicosapentaenoic acid.

${ }^{4} \mathrm{DHA}=$ docosahexaenoic acid.

${ }^{5}$ Unidentifiable peaks.

${ }^{6}$ Short-chain FA: (C4:0 to $\left.C 13: 0\right)$.

${ }^{7}$ Medium-chain FA: (C14:0 to $\left.C 17: 1\right)$.

${ }^{8}$ Long-chain FA: ( $\geq$ C18:0).

salts of canola oil. The lower availability of flaxseed oil for ruminal biohydrogenation may have been the reason for lack of differences in TVA concentration in milk from cows fed the $\mathrm{HO}$ and the HLN. The fact that total trans C18:1 FA were greater $(P<0.05)$ for the HO compared with the HLN supports this speculation and also explains the lower milk fat test with the $\mathrm{HO}$ compared with the HLN.

The proportions and yields of milk FA of chain lengths less than 18 carbons (C4:0 to $\mathrm{C} 17: 0)$ were greater $(P<$ 
0.05) for cows fed the HS than for cows fed other fat supplements. The reduction in the proportion of short and medium FA was greater with cows fed the HLO compared with the HO and the HLN. Feeding polyunsaturated and monounsaturated oils are typically associated with a decrease in the de novo synthesis of shortand medium-chain FA (Casper et al., 1988; AbuGhazaleh et al., 2002), with the greatest decrease when a high linoleic oil source is fed (Casper et al., 1988; Kelly et al., 1998). The decrease in medium-chain FA may represent an improvement in the profile of milk fat FA because these FA have been reported to constitute the hypercholesterolemic portion of milk fat (Ney, 1991). The greater concentration $(P>0.05)$ of C16:0 FA with the HS compared with the other diets may be attributed to grater intake of C16:0 FA with the HS (Table 4) or exogenous C16:0 FA stimulated synthesis and incorporation of $\mathrm{C} 16: 0 \mathrm{FA}$ into triacylglycerols by dispersed mammary gland epithelial cells in vitro (Hansen and Knudsen, 1987).

The concentration and yield of odd-chain FA in milk fat were decreased $(P<0.05)$ by the HO, HLO, and the HLN compared with the HS. Ruminal bacteria, which synthesize long-chain FA from odd-numbered volatile FA, are the major source of those odd-numbered-chain FA in milk fat (Harfoot and Hazlewood, 1988). How bacteria regulate their lipid composition is still unclear; however, it is well established that dietary lipids can alter the lipid composition of rumen bacteria (Harfoot and Hazlewood, 1988).

The addition of high oleic sunflower, regular sunflower, and flaxseeds increased $(P<0.05)$ the proportion and yield of C18:1 cis-9, C18:2 cis-9,cis-12, and C18:3 n3 FA in milk fat, respectively (Table 5 and 6). There were significantly different concentrations of C18:1 cis9 FA in milk fat among all treatments $(P<0.05)$, the level being least for the HS, followed by the HLN, HLO, and the HO. The proportion of C18:1 cis-9 FA decreased linearly as the unsaturation of the dominant FA in the fat supplements increased. The same response was also reported by Chouinard et al. (1998) when they fed calcium salts of FA that differed in the degree of unsaturation.

The increased intake of $\mathrm{C} 18: 2$ cis-9,cis- 12 and $\mathrm{C} 18: 3$ n3 FA with the HLO and the HLN, respectively (Table 4), had only minor effects on the proportion and yield of C18:2 cis-9,cis-12 and C18:3 n3 FA in milk fat (Table 5 and 6). These findings were also reported with other studies (Chouinard et al., 1998; Kelly et al., 1998; Chouinard et al., 2001). The low transfer of C18:2 cis9,cis-12 FA to milk fat in this study and others (Focant et al., 1998; Chouinard et al., 2001) suggested an extensive degree of ruminal biohydrogenation of C18:2 cis9,cis-12 FA. Wachira et al. (2000) reported that biohy- drogenation of C18:2 FA ranged between 80 and $93 \%$ when lambs were fed FO or whole linseed or both.

The proportion and yield of C18:3 $n 3 \mathrm{FA}$ in milk fat were highest with the HLN diet (Table 5 and 6). The high content of C18:3 n3 FA was expected in milk fat of these cows based upon the high content of C18:3 $n 3$ FA in the diet. However, the increase in C18:3 $n 3 \mathrm{FA}$ concentration in milk fat with the HLN was relatively low compared with intake. This low transfer of C18:3 $n 3$ FA from feed to milk fat may be explained either by ruminal biohydrogenation or by partitioning toward other tissues within the body. Because flaxseed shells mostly remained intact, extensive ruminal biohydrogenation of C18:3 $n 3 \mathrm{FA}$ was less likely. Kitessa et al. (2001) reported that C18:3 $n 3 \mathrm{FA}$ is almost totally confined to plasma cholesterol ester and phospholipid which are poorly taken up by the mammary gland (Offer et al., 1999).

\section{CONCLUSIONS AND IMPLICATIONS}

Conjugated linoleic acid concentration in milk fat can be enhanced by the addition of FO along with monoand polyunsaturated FA to the diet, especially oils high in linoleic acid. Feeding lactating dairy cows a blend of FO and a high linoleic acid source (e.g., regular sunflower seeds) resulted in the greatest increases in the concentrations and yields of milk cis-9,trans-11 CLA and TVA. Feeding FO and sunflower seeds maintained milk production, milk protein percentages, and DMI but decreased milk fat percentages and yields compared with other fat supplements. Feeding lactating cows FO with sunflower seeds improved the nutritional value of milk and maintained production.

\section{ACKNOWLEDGMENTS}

We thank the employees of the South Dakota State University Dairy Research Facility for care of the cows and assistance in obtaining research data and Valley Queen Cheese Factory, Milbank, SD, for milk analysis. We also thank Tom Young, Onida, SD, for donating the high oleic sunflower seeds. This research was partially supported by a grant from the South Dakota Oilseeds Council.

\section{REFERENCES}

AbuGhazaleh, A. A., D. J. Schingoethe, A. R. Hippen, and K. F. Kalscheur. 2003. Conjugated linoleic acid and transvaccenic acid in rumen, plasma, and milk of cows fed fish oil and fats differing in saturation of 18 carbon fatty acids. J. Dairy Sci. 86: (Accepted).

AbuGhazaleh, A. A., D. J. Schingoethe, A. R. Hippen, and L. A. Whitlock. 2002. Feeding fish meal and extruded soybeans enhances the conjugated linoleic acid (CLA) content of milk. J. Dairy Sci. 85:624-631. 
Association of Official Analytical Chemists. 1997. Official Methods of Analysis. 16th ed. AOAC Intl., Gaithersburg, MD.

Banks, W., J. L. Clapperton, and A. K. Girdler. 1990. Effect of dietary unsaturated fatty acids in various forms on the de novo synthesis of fatty acids in the bovine mammary gland. J. Dairy Res. 57:179-185.

Belury, M. A. 1995. Conjugated dienoic linoleate: a polyunsaturated fatty acid with unique chemical properties. Nutr. Rev. 53:83-89.

Casper, D. P., D. J. Schingoethe, R. P. Middaugh, and R. J. Baer. 1988. Lactational responses of dairy cows to diets containing regular and high oleic sunflower seeds. J. Dairy Sci. 71:12671274.

Chilliard, Y., A. Ferlay, R. M. Mansbridge, and M. Doreay. 2000. Ruminant milk fat plasticity: nutritional control of saturated, polyunsaturated, trans and conjugated fatty acids. Ann. Zootech. 49:181-205.

Chouinard, P. Y., D. E. Bauman, B. A. Corl, L. H. Baumgard, M. A. MaGuire, and J. G. Giesy. 1999. An update on conjugated linoleic acid. Pages 93-101 in Proc. Cornell Nutr. Conf. Feed Manuf., Cornell Univ., Ithaca, NY.

Chouinard, P. Y., L. Corneau, W. R. Butler, Y. Chilliard, J. K. Drackley, and D. E. Bauman. 2001. Effect of dietary lipid source on conjugated linoleic acid concentrations in milk fat. J. Dairy Sci. 84:680-690.

Chouinard, P. Y., V. Girard, and G. J. Brisson. 1998. Fatty acid profile and physical properties of milk fat from cows fed calcium salts of fatty acids with varying unsaturation. J. Dairy Sci. 81:471-481.

Dhiman, T. R., L. D. Satter, M. W. Pariza, M. P. Galli, K. Albright, and M. X. Tolosa. 2000. Conjugated linoleic acid (CLA) content of milk from cows offered diets rich in linoleic and linolenic acid. J. Dairy Sci. 83:1016-1027.

Donovan, C. D., D. J. Schingoethe, R. J. Baer, J. Ryali, A. R. Hippen, and S. T. Franklin. 2000. Influence of dietary fish oil on conjugated linoleic acid and other fatty acids in milk fat from lactating dairy cows. J. Dairy Sci. 83:2620-2628.

Focant, M., E. Mignolet, M. Marique, F. Clabots, T. Breyne, D. Dalemans, and Y. Larondelle. 1998. The effect of vitamin E supplementation of cows diets containing rapeseed and linseed on the prevention of milk fat oxidation. J. Dairy Sci. 81:1095-1101.

Hansen, H. O., and J. Knudsen. 1987. Effect of exogenous long-chain fatty acids on individual fatty acid synthesis by dispersed ruminant mammary gland cells. J. Dairy Sci. 70:1350-1354.

Harfoot, C. G. 1981. Lipid metabolism in the rumen. Pages 21-54 in Lipid Metabolism in Ruminant Animals. W. W. Christie, Pergamon Press Ltd., Oxford, United Kingdom.

Harfoot, C. G., and G. P. Hazlewood. 1988. Lipid metabolism in the rumen. Pages 285-322 in The Rumen Microbial Ecosystem. P. N. Hobson, ed. Elsevier Applied Science Publishers, London, United Kingdom.

Kelly, M. L., J. R. Berry, D. A. Dwyer, J. M. Griinari, P. Y. Chouinard, M. E. Van Amburgh, and D. E. Bauman. 1998. Dietary fatty acid sources affect conjugated linoleic acid concentrations in milk from lactating dairy cows. J. Nutr. 128:881-885.
Kitessa, S. M., S. K. Gulati, J. R. Ashes, E. Fleck, T. W. Scott, and P. D. Nichols. 2001. Utilization of fish oil in ruminants I. Fish oil metabolism in sheep. Anim. Feed Sci. Technol. 89:189-199.

Lowry, J. B., L. L. Conlan, A. C. Schlink, and C. S. McSweeney. 1994. Acid detergent dispersible lignin in tropical grasses. J. Sci. Food Agric. 65:41-50.

Mosley, E. E., G. L. Powell, M. B. Riley, and T. C. Jenkins. 2002. Microbial biohydrogenation of oleic acid to trans isomers in vitro. J. Lipid Res. 43:290-296.

National Research Council. 2001. Nutrient Requirements of Dairy Cattle. 7th. rev. ed. Natl. Acad. Sci., Washington, DC.

Ney, D. M. 1991. Potential for enhancing the nutritional properties of milk fat. J. Dairy Sci. 74:4002-4012.

Offer, N. W., M. Marsden, J. Dixon, B. K. Speake, and F. E. Thacker. 1999. Effect of dietary fat supplements on levels of n-3 polyunsaturated fatty acids, trans acids and conjugated linoleic acid in bovine milk. Anim. Sci. 69:613-625.

Orth, R. 1992. Sample day and lactation report, DHIA 200. Fact Sheet A-2, Mid-states DRPC, Ames, IA.

Palmquist, D. L., and T. C. Jenkins. 1980. Fat in lactation rations:review. J. Dairy Sci. 63:1-14.

Parodi, P. W. 1997. Cow's milk fat components as potential anticarcinogenic agents. J. Nutr. 127:1055-1060.

Petit, H. V. 2002. Digestion, milk production, milk composition, and blood composition of dairy cows fed whole flaxseed. J. Dairy Sci. $85: 1482-1490$.

Robertson, J. B., and P. J. Van Soest. 1981. The detergent system of analysis and its application to human foods. Pages 123-129 in The Analysis of Dietary Fiber. W. P. T. James and O. Theander, ed. Marcel Dekker, New York, NY.

Salminen, I., M. Mutanen, M. Jauhiainen, and A. Aro. 1998. Dietary trans fatty acids increase conjugated linoleic acid levels in human serum. J. Nutr Biochem. 9(2):93-98.

SAS/STAT. Software: Changes and Enhancements Through Release 6.11. 1996. SAS Inst., Inc., Cary, NC.

Stegeman, G. A., D. P. Casper, D. J. Schingoethe, and R. J. Baer. 1992. Lactational responses of dairy cows fed unsaturated dietary fat and received bovine somatotropin. J. Dairy Sci. 75:1936-1945.

Van Soest, P. J., J. B. Robertson, and B. A. Lewis. 1991. Methods for dietary fiber, neutral detergent fiber, and non-starch polysaccharides in relation to animal nutrition. J. Dairy Sci. 74:35833597.

Wachira, A. M., L. A. Sinclair, R. G. Wilkinson, K. Hallett, M. Enser, and J. D. Wood. 2000. Rumen biohydrogenation of n-3 polyunsaturated fatty acids and their effects on microbial efficiency and nutrient digestibility in sheep. J. Agric. Sci. 135:419-428.

Whitlock, L., D. J. Schingoethe, A. R. Hippen, K. F. Kalscheur, R. J. Baer, N. Ramaswamy, and K. M. Kasperson. 2002. Fish oil and extruded soybeans fed in combination increase CLA in milk of dairy cows more than when fed separately. J. Dairy Sci. 85:234-243.

Wildman, E. E., G. M. Jones, P. E. Wagner, R. L. Bowman, H. F. Troutt, and T. N. Lesch. 1982. Dairy cow body condition scoring and its relationship to selected production characteristics. J. Dairy Sci. 65:495-501. 